ZOOLOGIA 31 (2): 153-161, April, 2014

http://dx.doi.org/10.1590/S1984-46702014000200006

\title{
Habitat use and seasonal activity of insectivorous bats (Mammalia: Chiroptera) in the grasslands of southern Brazil
}

\author{
Marília A. S. Barros ${ }^{1,3}$, Daniel M. A. Pessoaํ \& Ana Maria Rui² \\ 1 Departamento de Fisiologia, Centro de Biociências, Universidade Federal do Rio Grande do Norte. Campus Universitário \\ Lagoa Nova, 59078-970 Natal, RN, Brazil. \\ 2 Departamento de Ecologia, Zoologia e Genética, Instituto de Biologia, Universidade Federal de Pelotas. Campus \\ Universitário Capão do Leão, Caixa Postal 354, 96001-970 Pelotas, RS, Brazil. \\ ${ }^{3}$ Corresponding author E-mail: barrosmas@gmail.com
}

\begin{abstract}
In temperate zones, insectivorous bats use some types of habitat more frequently than others, and are more active in the warmest periods of the year. We assessed the spatial and seasonal activity patterns of bats in open areas of the southernmost region of Brazil. We tested the hypothesis that bat activity differs among habitat types, among seasons, and is influenced by weather variables. We monitored four 1,500-m transects monthly, from April 2009 to March 2010. Transects corresponded to the five habitat types that predominate in the region. In each sampling session, we detected and counted bat passes with an ultrasound detector (Pettersson D230) and measured climatic variables at the transects. We recorded 1,183 bat passes, and observed the highest activity at the edge of a eucalyptus stand (0.64 bat passes $/ \mathrm{min}$ ) and along an irrigation channel ( 0.54 bat passes $/ \mathrm{min})$. The second highest activity values ( 0.31 and 0.20 bat passes/min, respectively) were obtained at the edge of a riparian forest and at the margin of a wetland. The grasslands were used significantly less ( 0.05 bat passes $/ \mathrm{min})$. Bat activity was significantly lower in the winter $(0.21$ bat passes $/ \mathrm{min}$ ) and showed similar values in the autumn ( 0.33 bat passes $/ \mathrm{min})$, spring $(0.26$ bat passes $/ \mathrm{min})$, and summer (0.29 bat passes $/ \mathrm{min})$. Bat activity was correlated with temperature, but it was not correlated with wind speed and relative humidity of the air. Our data suggest that, in the study area, insectivorous bats are active throughout the year, and use mostly forest and watercourses areas. These habitat types should be considered prioritary for the conservation of bats in the southernmost region of Brazil.
\end{abstract}

KEY WORDS. Acoustic monitoring; activity patterns; Molossidae; South American Pampas; Vespertilionidae.

Insectivorous bats represent $70 \%$ of all bat species and are widely distributed (Simmons 2005). They play an important ecological role in the transfer of nutrients in ecosystems (PIERSON 1998) and in the control of insect populations, including agricultural pests (Boyles et al. 2011). Insectivorous bats occupy high trophic levels, are indicators of habitat quality (Jones et al. 2009), and may undergo population decrease in response to environmental disturbances (TutTLE 1979, Gerell \& LUNDBERG 1993, O'DONNELL 2000).

In temperate zones, insectivorous bats use some types of habitat more frequently than others, and tend to respond positively to the presence of trees and water bodies (WALSH \& HARRIS 1996). Bats are highly active in forests and forest fragments in rural areas (ERICKSON \& WEST 2003, LUMSDEN \& BENNETT 2005), mainly in hedgerows and forest edges (Russ et al. 2003, Реттіт \& WiLKINS 2012), as well as around rivers, lakes, and lagoons (VAughan et al. 1997, Brooks 2009). Furthermore, in temperate regions the activity levels of bats vary seasonally in response to fluctuations in climatic conditions and their own energy requirements throughout the year (Ciechanowski et al. 2010, Johnson et al. 2011). Some studies highlighted the influence of abiotic factors on bat activity, such as temperature (HAYEs 1997, Russ et al. 2003), wind speed (Avery 1985, JoHnson et al. 2011), and relative humidity of the air (LACKI 1984, ADAm et al. 1994).

There is plenty of information available about habitat use and seasonal activity of insectivorous bats, which is mainly based on studies carried out in temperate regions of the northern hemisphere. In Brazil, studies focusing on habitat use by insectivorous bats are few, though there is one study carried out in an urban area in southeastern Brazil (Almeida et al. 2007). One of the places where the Brazilian bat fauna is understudied is the state of Rio Grande do Sul, mainly its southern half, where the Pampa biome is located (BERNARD et al. 2011). The Pampa biome corresponds to the Brazilian part of the South American Pampas, which extends through Uruguay and Argentina and is characterized by plains covered by grasslands (IBGE 2004). Although the Pampa covers approximately $2 \%$ of the Brazilian territory (IBGE 2004), it occupies the third place

2014 Sociedade Brasileira de Zoologia | www.sbzoologia.org.br | www.scielo.br/zool All content of the journal, except where identified, is licensed under a Creative Commons attribution-type BY-NC. 
among the six continental biomes of Brazil in terms of number of endangered species, surpassing even the Amazon, Caatinga, and Pantanal (PAglia et al. 2008). The main threats to the biodiversity of the Pampa are the expansion of agriculture, silviculture, and exotic grasses, which have been responsible for a considerable loss of natural grasslands in the past three decades (Pillar et al. 2009).

Information about patterns of habitat use is important for bat conservation (FENTON 1997) and, hence, for the conservation of ecological processes associated with bats. In the present study, we describe spatial and seasonal activity patterns of insectivorous bats in the southernmost region of Brazil, in a Pampa area. Our objectives were: a) to compare the main characteristic habitats of this region in terms of bat activity; b) to test for seasonal variations in bat activity; and c) to test whether bat activity is influenced by abiotic factors, such as temperature, wind speed, and relative humidity of the air. We hypothesized that bat activity is higher in habitats with trees and/or water, and also that bats decrease their activity in the colder months of the year.

\section{MATERIAL AND METHODS}

We carried out the present study in private properties of the rural area of Santa Vitória do Palmar, in the southernmost region of the state of Rio Grande do Sul, Brazil. The study area is located in the geomorphologic region of Planície Costeira (a coastal lowland), in the Pampa biome, classified as steppe according to the international phytogeographic system of world vegetation (IBGE 2004).

The landscape is wide lowland with sandy grasslands, located between Mirim Lagoon and the Atlantic Ocean. The predominant vegetation in the region is grassland, which is mainly formed by grasses, sedges, and other herbs and subshrubs (RAMBO 2000). In areas under freshwater influence there is paludal and shrubby vegetation, forming small riparian forests along watercourses (RAмво 2000). In addition, there are lines and stands of introduced eucalyptus isolated in the grassland, planted to serve as windbreaks and shelter for farm livestock.

According to the Köppen system, the climate of the region is classified as Cfa, i.e., temperate without dry season and with hot summer (Peel et al. 2007). According to data obtained between 1990 and 2010 at the meteorological station of Santa Vitória do Palmar (Instituto Nacional de Meteorologia/INMET), the average annual temperature is $17^{\circ} \mathrm{C}$. The coldest months are June and July, with an average temperature of $12^{\circ} \mathrm{C}$, and the warmest months are January and February, with an average temperature of $22^{\circ} \mathrm{C}$. The average monthly rainfall is $109 \mathrm{~mm}$, and the annual total rainfall was 1,153 $\mathrm{mm}$ in 2009 and 1,176 in 2010 .

The term "activity" has broad meaning; in our study we are referring to the flight/foraging activity of bats, outside day roosts. Monitoring of bat activity was carried out in four 1,500$\mathrm{m}$ long transects, located in the different types of habitats that predominate in the region (Table I, Figs 1-6. 1). We marked 30 fixed points at each transect, $50 \mathrm{~m}$ away from each other. We marked the transects TR II and TR IV in structurally homogeneous environments in terms of vegetation, and considered them to contain the same type of habitat. Transects TR I and TR III comprised two types of habitat each. Each point at the transects comprised only one type of habitat, considering the type of vegetation in a radius of $50 \mathrm{~m}$ around the point.

Every month from April 2009 to March 2010 we monitored one transect each night and, whenever possible, during four consecutive nights. We used the ultrasound detector Pettersson Elektronik AB D230 (frequency range: 10-120 kHz, bandwidth: $8 \mathrm{kHz} \pm 4 \mathrm{kHz}$ ), in the mode heterodyne, which artificially reduces the ultrasound frequency and makes it audible to humans in real time (PArsons \& Szewczak 2009). The transects were always monitored by the same observer, and the ultrasound detector was used for three minutes in each one of the 30 points. Transect monitoring began 10 minutes after sunset and was carried out at night when it was not raining. At each point, the observer kept the ultrasound detector at approximately $1 \mathrm{~m}$ above ground, at $45^{\circ}$ of inclination, and turned it $360^{\circ}$ covering all directions. For each point, we recorded the number of bat passes, which are defined as a sequence of a bat echolocation calls on the detector from beginning to end (following KuENzI \& Morrison 2003). To increase the chance of recording the highest possible number of species, we constantly altered the frequency of the bat detector between 10 and $120 \mathrm{kHz}$ (following CeLuCH \& KROPIL 2008).

We considered the activity of the bat assemblage as a whole. Spatial and seasonal activity patterns may vary among species (BRooks \& Ford 2005, Ciechanowski et al. 2010), but information on general bat activity is useful for the identification of general tendencies of habitat use and priority areas for bat conservation (EstRADA et al. 2004, WALSH \& HARRIS 1996). In the study area, the fauna of insectivorous bats corresponds to molossid and vespertilionid species, and sampling with mist nets confirmed the presence of Tadarida brasiliensis (I. Geoffroy, 1824), Molossus molossus (Pallas, 1766), Molossus rufus É. Geoffroy, 1805, and Eptesicus brasiliensis (Desmarest, 1819) in the region (M.A.S. Barros, unpublished data) - although probably more species occur in the area.

The sampling effort was 72 hours on 48 sampling nights. The average time to completely monitor transects was $132.4 \pm$ 9.5 minutes (time with the bat detector switched on plus movement time on foot between points). According to information from temperate zones of North America (Kunz 1973, Hayes 1997), and also to data from other parts of the region of Planície Costeira in Rio Grande do Sul (Rui \& Barros, unpublished data), our survey was carried out in the typical activity peak of insectivorous bats in the first two-three hours after sunset. Because of this, we assume that the timing of activity monitoring did not bias our results, and transects were always surveyed in the same direction (from point 1 to 30 ). 

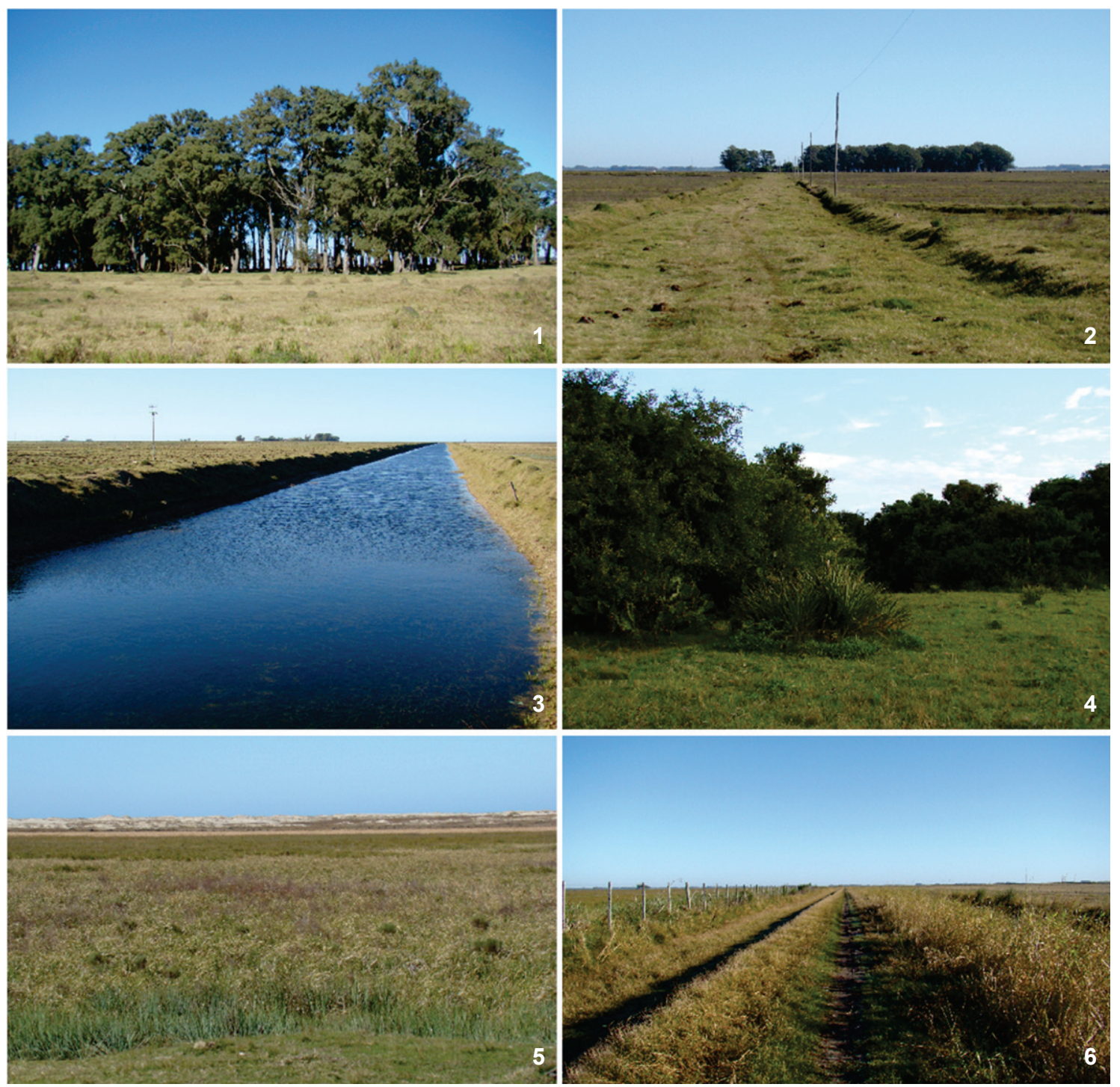

Figures 1-6. Habitat types monitored for bat activity with acoustic surveys, from April 2009 to March 2010, in the grasslands of southernmost Brazil: (1) Eucalyptus stand (TR I); (2) Grassland (TR I); (3) Channel (TR II); (4) Riparian forest (TR III); (5) Wetland (TR III); (6) Grassland (TR IV).

Table I. Transects and habitat types monitored for bat activity with acoustic surveys, from April 2009 to March 2010, in the grasslands of southernmost Brazil.

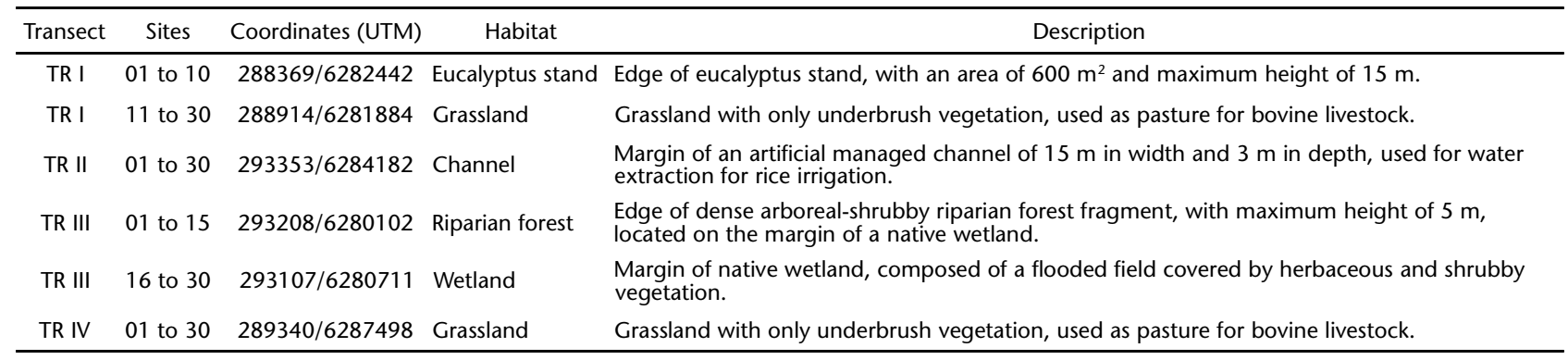


We recorded the following abiotic parameters: temperature, relative humidity of the air, and wind velocity. We collected these data four times while monitoring transects: at point 01 (beginning of the transect), at point $10(500 \mathrm{~m})$, at point 20 $(1,000 \mathrm{~m})$, and at point 30 (end of the transect).

The statistical analysis was carried out in the program PASW Statistics 18 (Statistical Package for the Social Sciences/ SPSS Inc.). Since our data were not normally distributed (Kolmogorov-Smirnov test, $\alpha=0.01$ ), we used non-parametric tests.

We compared the number of bat passes/3 min among the five habitat types, pooling the 12 sampling months, and compared bat activity between habitats for each season. In both analyses, we used Kruskal-Wallis tests $(\alpha=0.05)$ and MannWhitney post hoc tests ( $\alpha=0.005$, with Bonferroni correction).

For the assessment of seasonal variations in bat activity, we compared the number of bat passes/3 min among seasons, pooling data of the five types of habitats. We also compared bat activity among seasons for each habitat alone, carrying out five additional analyses, one for each type of habitat. For these analyses, we used the Friedman ANOVA $(\alpha=0.05)$ and the Wilcoxon post hoc test ( $\alpha=0.008$ with Bonferroni correction).

To assess the influence of abiotic factors on bat activity, we calculated correlations between the number of bat passes and temperature $\left({ }^{\circ} \mathrm{C}\right)$, relative humidity of the air $(\%)$, and wind speed $(\mathrm{m} / \mathrm{s})$, with the Spearman coefficient $(\alpha=0.05)$. Since the abiotic factors were measured only four times when we monitored transects, and did not vary much from one point to the next, we extrapolated the values measured in one point to its neighbors. For the analyses, we extrapolated the abiotic data obtained at point 01 to points 02 to 05 , the data of point 10 to points 6 to 15 , the data of point 20 to points 16 to 25 , and the data of point 30 to points 26 to 29 .

\section{RESULTS}

\section{Use of habitat by bats}

We recorded 1,183 bat passes during one year. Bat activity differed significantly among habitat types $(\mathrm{H}=311.38, \mathrm{df}=$ $4, \mathrm{p}<0.001)$. We observed the highest activity in the eucalyptus stand and in the channel, followed by the riparian forest and the wetland (Fig. 7). The grassland was the least used habitat (Fig. 7). All habitats differed from each other $(p<0.001)$, except for the comparisons "eucalyptus vs. channel" $(p=0.038)$ and "riparian forest vs. wetland" ( $p=0.162)$ (Fig. 8).

Bat activity differed also among habitat types in the different seasons (Fig. 9). The difference in activity among habitats was significant in the autumn $(\mathrm{H}=190.56$, $\mathrm{df}=4$, $\mathrm{p}<0.001)$, the winter $(\mathrm{H}=81.65, \mathrm{df}=4, \mathrm{p}<0.001)$, the spring $(\mathrm{H}=71.48, \mathrm{df}=4, \mathrm{p}<0.001)$, and the summer $(\mathrm{H}=90.54, \mathrm{df}=$ $4, \mathrm{p}<0.001)$. In the autumn, the highest activity levels were recorded in the eucalyptus stand and in the channel; all habitats differed from each other $(p \leqslant 0.002)$, except for the com-

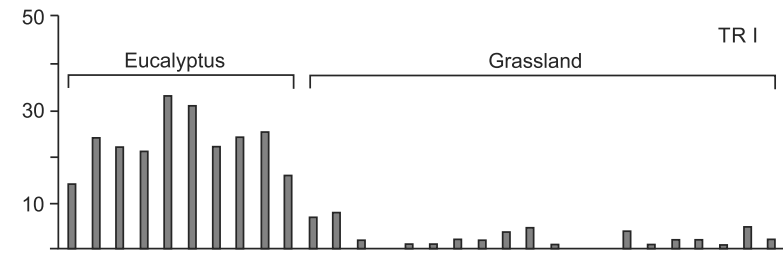

123456789101112131415161718192021222324252627282930

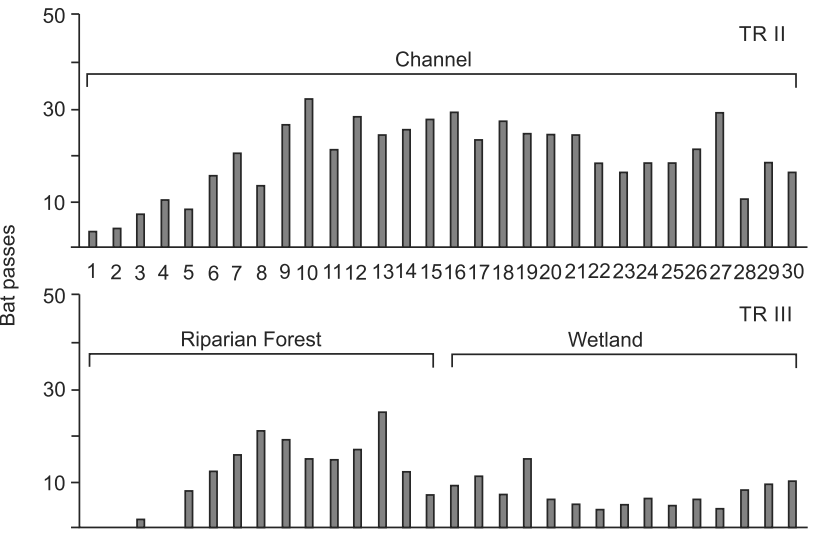

123456789101112131415161718192021222324252627282930

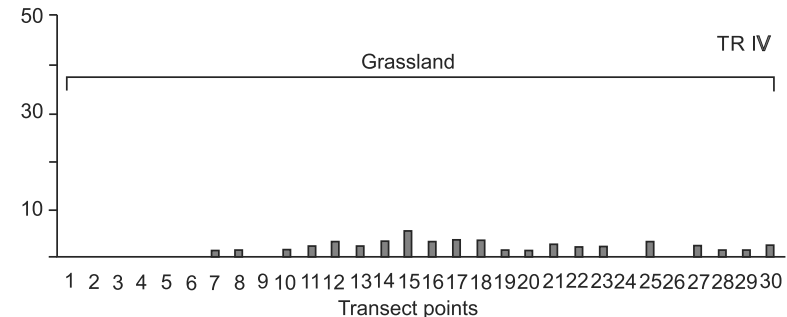

Figure 7. Total number of bat passes recorded with a bat detector in each fixed point on 1,500-m transects monitored for bat activity, from April 2009 to March 2010, in the grasslands of southernmost Brazil.

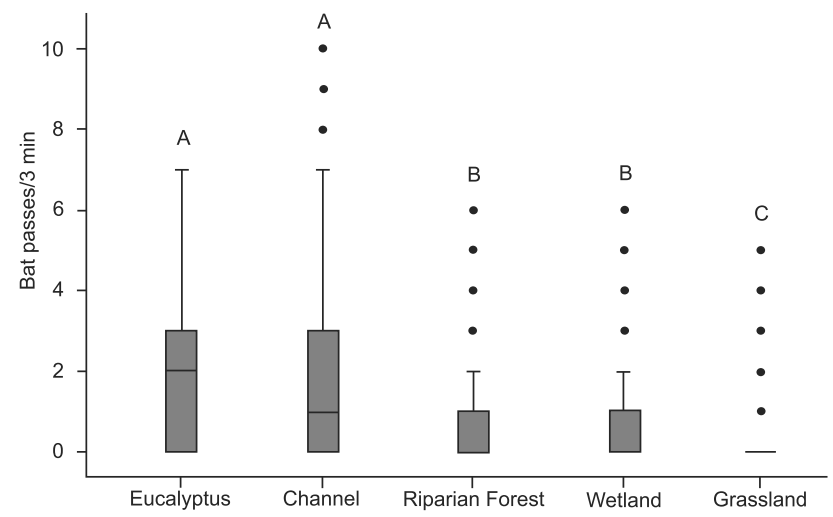

Figure 8 . Box plot of the number of bat passes $/ 3$ min recorded with a bat detector in each habitat type, from April 2009 to March 2010, in the grasslands of southernmost Brazil. Different letters indicate significant differences at the 0.005 probability level (with Bonferroni correction). 

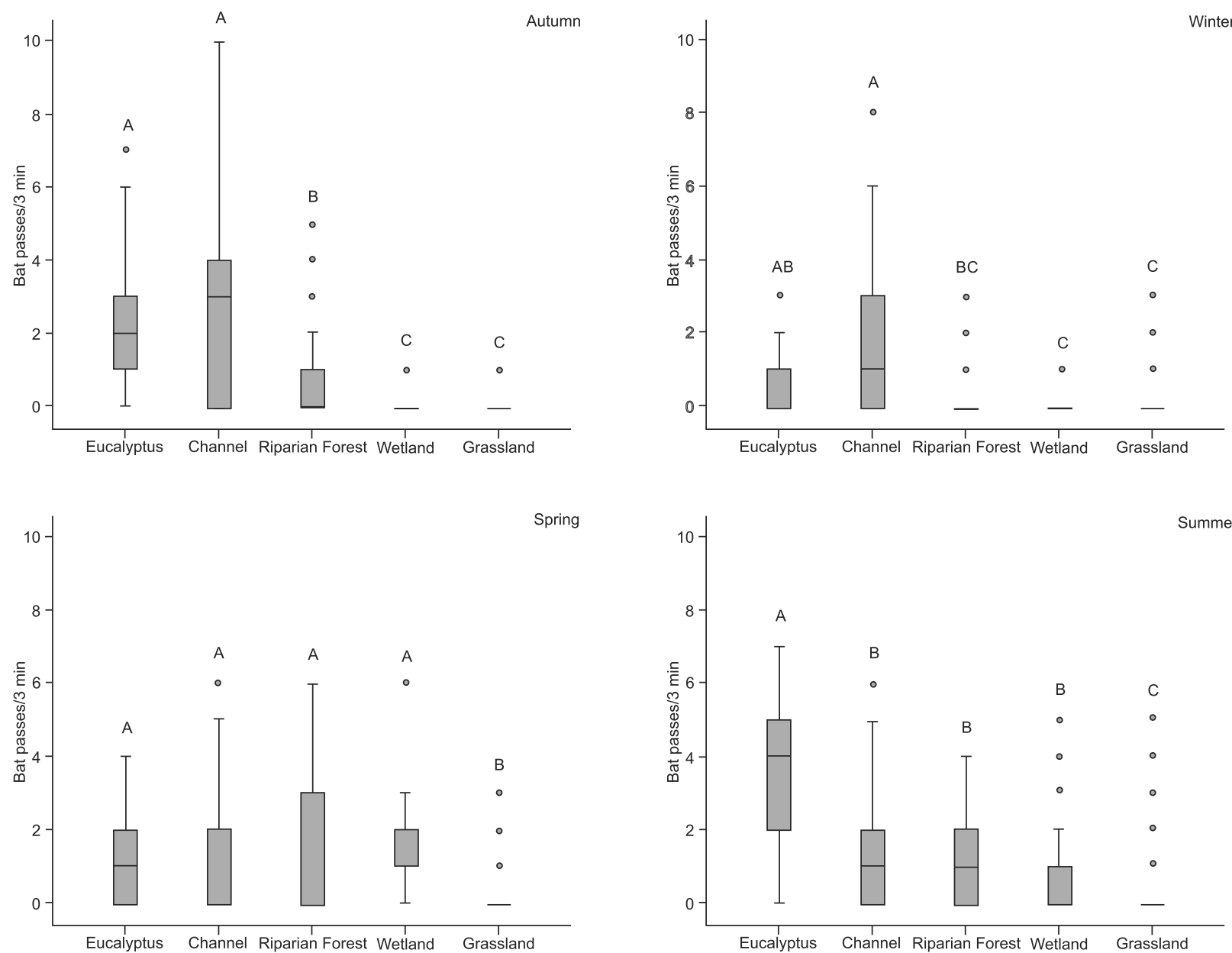

Figure 9. Box plot of the number of bat passes/3 min recorded with a bat detector in each habitat type in different seasons, from April 2009 to March 2010, in the grasslands of southernmost Brazil. Different letters indicate significant differences at the 0.005 probability level (with Bonferroni correction).

parisons "eucalyptus vs. channel" ( $\mathrm{p}=0.834)$ and "grasslands vs. wetland" ( $\mathrm{p}=0.113)$. In the winter, activity was higher in the channel than in the other habitats $(\mathrm{p}<0.001)$, except for the eucalyptus stand $(\mathrm{p}=0.018)$. In the spring, bat activity was lower in the grassland than in the other habitats $(\mathrm{p}<0.001)$ which did not differ from each other $(p \geqslant 0.010)$. In the summer, the eucalyptus stand showed the highest activity, differing from all other types of habitats $(\mathrm{p}<0.001)$.

\section{Seasonal variations in bat activity}

Bat activity varied among seasons $\left(\mathrm{F}_{\mathrm{r}}=10.34, \mathrm{df}=3, \mathrm{p}=\right.$ 0.016). There was no significant difference in the number of bat passes between the autumn (356 bat passes in total), summer (316), and spring (282) ( $p \geqslant 0.116)$. The number of bat passes in the winter (229) was significantly smaller than in the autumn and summer $(\mathrm{p} \leqslant 0.004)$, and statistically similar to the number of bat passes in the spring $(p=0.106)$.
We also observed seasonal variations in bat activity for each habitat alone, in the eucalyptus stand $\left(\mathrm{F}_{\mathrm{r}}=36.42\right.$, $\mathrm{df}=3$, $\mathrm{p}<0.001)$, the channel $\left(\mathrm{F}_{\mathrm{r}}=32.46, \mathrm{df}=3, \mathrm{p}<0.001\right)$, the riparian forest $\left(\mathrm{F}_{\mathrm{r}}=12.12, \mathrm{df}=3, \mathrm{p}=0.007\right)$, the wetland $\left(\mathrm{F}_{\mathrm{r}}=61.94\right.$, $\mathrm{df}=3, \mathrm{p}<0.001)$, and the grassland $\left(\mathrm{F}_{\mathrm{r}}=28.14, \mathrm{df}=3, \mathrm{p}<0.001\right)$. In the eucalyptus stand, riparian forest, wetland and grassland, the highest bat activity was observed in the spring and summer (Fig. 10). However, in the channel, bat activity was higher in the autumn and winter; bat activity in the autumn was significantly higher than in the other seasons $(p \leqslant 0.006)$ (Fig. 10).

\section{Influence of climatic factors in bat activity}

In the winter we recorded the lowest average temperature, and also the highest humidity and highest wind speed (Table II). We observed the highest bat activity ( $\geqslant 7$ bat passes/ $3 \mathrm{~min}$ ) in the points where the temperature was higher than $15^{\circ} \mathrm{C}$, and we observed null or very low values ( $\leqslant 1$ bat pass/ 


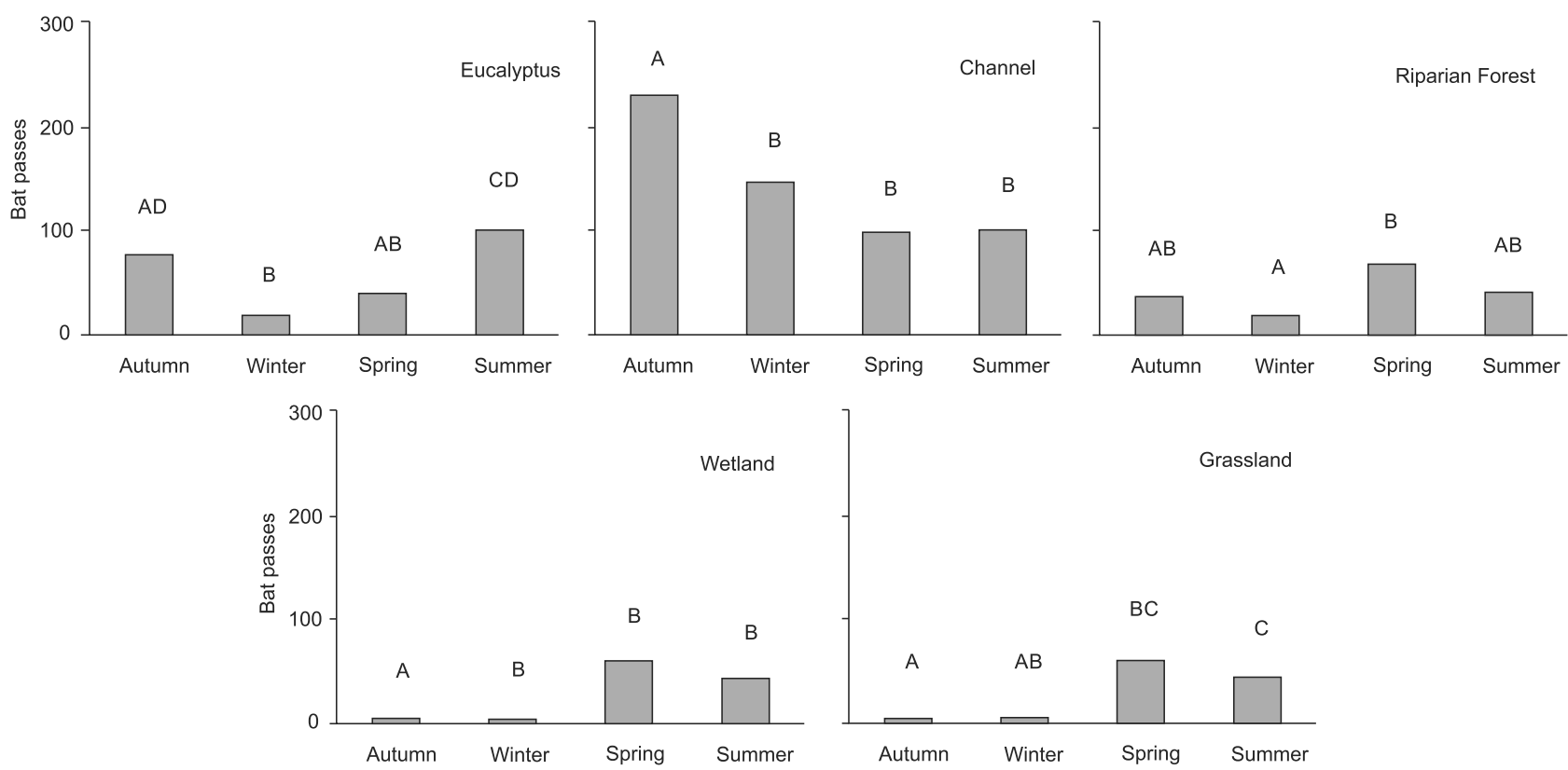

Figure 10. Total number of bat passes recorded with a bat detector in each season for the five habitat types, from April 2009 to March 2010, in the grasslands of southernmost Brazil. Different letters indicate significant differences at the 0.008 probability level (with Bonferroni correction).

Table II. Average values and standard deviation of the climatic factors measured in the transects monitored for bat activity, from April 2009 to March 2010, in the grasslands of southernmost Brazil.

\begin{tabular}{lccc}
\hline \multicolumn{1}{c}{ Season } & Temperature $\left({ }^{\circ} \mathrm{C}\right)$ & Humidity $(\%)$ & Wind speed $(\mathrm{m} / \mathrm{s})$ \\
\hline Autumn & $15.0 \pm 4.7$ & $80.5 \pm 9.5$ & $1.5 \pm 1.6$ \\
Winter & $11.9 \pm 2.5$ & $92.7 \pm 5.3$ & $2.6 \pm 1.5$ \\
Spring & $14.7 \pm 4.5$ & $88.7 \pm 8.9$ & $2.1 \pm 1.3$ \\
Summer & $17.8 \pm 2.3$ & $85.2 \pm 11.8$ & $1.2 \pm 0.9$ \\
\hline
\end{tabular}

$3 \mathrm{~min}$ ) when temperatures were between $5^{\circ} \mathrm{C}$ and $10^{\circ} \mathrm{C}$. The number of bat passes was correlated with temperature $\left(\mathrm{r}_{\mathrm{s}}=\right.$ $0.138, \mathrm{p}<0.001)$. We recorded high levels of activity ( $\geqslant 7$ bat passes/3 min) in nights with different values of wind speed and relative humidity of the air. Bat passes were not significantly correlated with relative humidity of the air $\left(r_{s}=0.009\right.$, $\mathrm{p}=0.722)$ or wind speed $\left(\mathrm{r}_{\mathrm{s}}=-0.030, \mathrm{p}=0.258\right)$.

\section{DISCUSSION}

\section{Use of habitat}

The hypothesis that bats mostly use areas with tall trees and water bodies was corroborated. The association of insectivorous bats with forest edges has been broadly documented for other regions (LumsDen \& BeNNeTt 2005, КоFoKy et al. 2007, MorRIs et al. 2010). This is also true for aquatic habitats (LUNDE \& Harestad 1986, Vaughan et al. 1997, Brooks 2009). The use of the eucalyptus stand and the channel were probably due to the availability of aerial insects, which are frequently abundant in forest edges (LewIs 1970) and water bodies (BARCLAY 1991).

The canopy of the eucalyptus stand is approximately three times higher than the canopy of the riparian forest. Since linear vegetation edges serve as landmarks and also offer protection against the wind and predators (LIMPENS \& KAPTEYN 1991), eucalyptus probably are more efficient for spatial orientation and protection than riparian forest. In addition, the eucalyptus trees have a large diameter, a reasonable space between each other, and trunks with cavities, cracks and loose bark, which favors their use as diurnal roost by bats, and also for flights inside the stand. The vegetation of the riparian forest, on the contrary, harbors trees with smaller diameter and high density, a factor that is negatively correlated with bat activity (ERICKSON \& WEST 2003).

In southern Brazil, there are records of association between insectivorous bats and tree species introduced for commercial use (Pinus spp.), which are used by vespertilionid bats to roost during the day (BARRos \& RuI 2011). Exotic trees tends to acquire particular significance when the original vegetation has been altered and the availability of tall native trees is reduced. In the study area, the natural vegetation is known as Butiazal, which is composed of jelly palm (Butia capitata) clusters that occur along the coastal lowland of southern Brazil (RAмво 2000). These formations are currently rare in the state of Rio Grande do Sul, and Butia capitata is endangered in the state (Rio Grande do Sul 2002). 
The channel may represent an important water source, since frequent water ingestion is a critical factor for the water balance of insectivorous bats (NeUWEILER 2000). Since insectivorous bats use watercourses for spatial orientation (RACEY \& SWIFT 1985, SerRA-Сово et al. 2000), the channel can also be used as a flying route. Apparently, the presence of open water is important for bat activity, since the channel showed higher activity levels than the wetland, where portions of flooded grassland are completely covered by vegetation. A study carried out in temporary lakes showed that the activity of insectivorous bats decreases as the exposed water area decreases (Francl et al. 2008). Insect availability in riparian areas may be high (RACEY \& SWIFT 1985). However, the activity of bats that forage over water may be negatively correlated with the presence of floating vegetation, which hinders the detection of prey through echolocation (Ciechanowski et al. 2007, Siemers et al. 2001).

The low bat activity in the grassland was expected, since insectivorous bats, in general, use field and pasture areas less frequently (Fenton 1970, Estrada et al. 2004). The activity recorded for grasslands is probably a result of the movement of individuals between roosts and feeding areas, or between feeding areas.

In all seasons, the eucalyptus stand and the channel were the habitats with highest activity, except in the spring. During this season, strong rains caused a more intense flood in the riparian forest and the wetland, which attracted more bats in relation to other seasons of the year, probably due to an increase in insect abundance.

Our data suggest that watercourses and edges of tree stands are priority habitats for bat conservation in the region. Areas of native wetland, with and without riparian forest, were less used, but also presented expressive levels of bat activity. The association of these types of habitat with insectivorous bats indicates that alterations in aquatic habitats or removal of trees tend to negatively affect bat activity in the region.

\section{Seasonal variations in bat activity and influence of climatic factors}

As expected, bat activity varied seasonally, and activity in the winter was low. This result is consistent with the common pattern observed for insectivorous bats (HaYs et al. 1992, Carmel \& SAfriel 1997, Hayes 1997). The winter is the most critical period for the energy balance of insectivorous bats because low temperatures reduce insect abundance and activity (TAYLOR 1963, Wolda 1988) and increase heat loss (RANSOME 1990), making foraging less profitable. In the study area, bat activity was positively correlated with temperature, as in other temperate regions (Avery 1985, BRooks 2009, Broders et al. 2006), and the low activity levels in winter was a response of bats to low temperatures.

Like other authors (e.g., Johnson et al. 2011, VеRвоOм \& SPOELSTRA 1999), we did not detect a significant relationship between bat activity and humidity or wind speed. In the study area, the climate frequently varies more expressively in terms of temperature than in terms of humidity or wind speed (RAmBo 2000). In southern Brazil, rainfall is uniform throughout the year and the relative humidity of the air during our sampling period was never below $60 \%$, which may explain the apparent lack of response of bats to variations in humidity. In addition, the wind may affect bat activity only when wind speed is high (> 4 m/s) (O'Farrell et al. 1967, O'FarRell \& Bradley 1970), which was rarely observed in our sampling period. The lack of a correlation between bat activity and climatic factors may also result from the pooled analysis of the bat assemblage, since some species at an area may be influenced by specific climatic factors, such as wind speed, whereas others may not (Russo \& Jones 2003, Russ et al. 2003).

We observed a tendency for high bat activity in the summer and spring and low activity in the winter in the eucalyptus stand, grassland, riparian forest and wetland. By contrast, in the channel, the spring and summer were the periods when bat activity was the lowest. This pattern is probably associated with the cultivation of rice in the area. From the beginning of spring to the end of summer, the grassland is removed, the soil is plowed and flooded, and the crop is treated with pesticides. It is likely that these actions may have negatively influenced bat activity in the channel, since bat activity is lower in areas with intensively managed crops (WALSH \& HARRIS 1996), probably due to a reduction in insect availability due to pesticides (Carmel \& Safriel 1998, Wickramasinghe et al. 2003).

Our study first demonstrated that insectivorous bats show seasonal variation in activity in the grasslands of southern Brazil (Pampa biome). Their activity patterns are markedly reduced in the winter, and are influenced by temperature.

\section{ACKNOWLEDGMENTS}

Rodrigo G. de Magalhães, Leandro V. Umann, Marcelo D. Freire, Estevão J.Comitti, Cristian M. Joenck, and Jeferson Bugoni provided us with logistic support in the study area. We thank Edison C. de Souza for the great help and friendship during fieldwork. Felipe N. Castro helped us in the statistical analysis. The company Maia Meio Ambiente LTDA granted us financial support. Coordenação de Aperfeiçoamento Pessoal de Nível Superior (CAPES) granted M.A.S. Barros a Master's scholarship.

\section{LITERATURE CITED}

Adam, M.D.; M.J. Lacki \& L.G. Shoemaker. 1994. Influence of environmental conditions on flight activity of Plecotus townsendii virginianus (Chiroptera: Vespertilionidae). Brimleyana 21: 77-85.

Almeida, M.H.; A.D. Ditchifield \& R.S. Tokumaru. 2007. Atividade de morcegos e preferência por hábitat na zona urbana da Grande Vitória, ES, Brasil. Revista Brasileira de Zoociências 9 (1): 13-18. 
AvERY, M.I. 1985. Winter activity by pipistrelle bats. Journal of Animal Ecology 54 (3): 721-738.

Barclay, R.M.R. 1991. Population Structure of Temperate Zone Insectivorous Bats in Relation to Foraging Behaviour and Energy Demand. Journal of Animal Ecology 60 (1): 165-178.

Barros, M.A.S. \& A.M. RuI. 2011. Occurrence and Mortality of Lasiurus ega (Chiroptera, Vespertilionidae) in Monocultures of Pinus sp. in Rio Grande do Sul, Southern Brazil. Chiroptera Neotropical 17 (2): 997-1002.

Bernard, E.; L.M.S. Aguiar \& R.B. Machado. 2011. Discovering the Brazilian bat fauna: a task for two centuries? Mammal Review 41 (1): 23-39. doi: 10.1111/j.1365-2907.2010.00164.x.

Boyles, J.G.; P.M. Cryan; G.F. McCracken \& T.H. Kunz. 2011. Economic Importance of Bats in Agriculture. Science 332 (6025): 41-42. doi: 10.1126/science.1201366.

Broders, H.G.; G.J. Forbes; S. Woodley \& I.D. Thompson. 2006. Range extent and stand selection for roosting and foraging in forest-dwelling northern long-eared bats and little brown bats in the Greater Fundy ecosystem New Brunswick. Journal of Wildlife Management 70 (5): 1174-1184. doi: 10.2193/0022-541X(2006)70[1174:REASSF]2.0.CO;2.

BRooks, R.T. 2009. Habitat-associated and temporal patterns of a bat activity in a diverse forest landscape of southern New England, USA. Biodiversity and Conservation 18 (3): 529 545. doi: 10.1007/s10531-008-9518-x.

BRooks, R.T. \& W.M. Ford. 2005. Bat activity in a forest landscape of Central Massachusetts. Northeastern Naturalist 12 (4): 447462. doi: 10.1656/1092-6194(2005)012[0447:BAIAFL]2.0.CO;2.

CARMEL, Y. \& U. SAFrifL. 1998. Habitat use by bats in a Mediterranean ecosystem in Israel-conservation implications. Biological Conservation 84 (3): 245-250. doi: 10.1016/S0006-3207(97) 00131-6.

Celuch, M. \& R. Kropil. 2008. Bats in a Carpathian beech-oak forest (Central Europe): habitat use, foraging assemblages and activity patterns. Folia Zoologica 57 (4): 358-372.

Ciechanowski, M.; T. Zaj ${ }^{1}$ C; A. Bitas \& R. Dunajski. 2007. Spatiotemporal variation in activity of bat species differing in hunting tactics: effects of weather, moonlight, food abundance, and structural clutter. Canadian Journal of Zoology 85 (12): 1249-1263. doi: 10.1139/Z07-090.

Ciechanowski, M.; T. Zaj ${ }^{1}$ C; A. Zieliñska \& R. Dunajski. 2010. Seasonal activity patterns of seven vespertilionid bat species in Polish lowlands. Acta Theriologica 55 (4): 301-314. doi: 10.4098/j.at.0001-7051.093.2009.

ERICKSON, J.L. \& S.D. WeST. 2003. Associations of bats with local structure and landscape features of forested stands in western Oregon and Washington. Biological Conservation 109 (1): 95-102. doi: 10.1016/S0006-3207(02)00141-6.

Estrada, A.; C. Jiménez; A. Rivera \& E. Fuentes. 2004. General bat activity measured with an ultrasound detector in a fragmented tropical landscape in Los Tuxtlas, Mexico. Animal Biodiversity and Conservation 27 (2): 1-9.

FEnTon, M.B. 1970. A technique for monitoring bat activity with results obtained from different environments in southern
Ontario. Canadian Journal of Zoology 48 (4): 847-851. doi: 10.1139/z70-148.

Fenton, M.B. 1997. Science and the Conservation of Bats. Journal of Mammalogy 78 (1): 1-14.

FranCL, K.E. 2008. Summer bat activity at woodland seasonal pools in the Northern Great Lakes Region. Wetlands 28 (1): 117-124. doi: 10.1672/07-104.1.

Gerell, R. \& K.G. Lundberg. 1993. Decline of a bat Pipistrellus pipistrellus population in an industrialized area in south Sweden. Biological Conservation 65 (2): 153-157. doi: 10.1016/0006-3207(93)90444-6.

HAYES, J.P. 1997. Temporal variation in activity of bats and the design of echolocation-monitoring studies. Journal of Mammalogy 78 (2): 514-524.

Hays, G.C.; J.R. Speakman \& P.I. Webb. 1992. Why do brown longeared bats (Plecotus auritus) fly in winter? Physiological Zoology 65 (3): 554-567.

IBGE. 2004. Mapa de Biomas do Brasil. Ministério do Meio ambiente, Instituto Brasileiro de Geografia e Estatística. Available online at: http://www.ibge.gov.br/home/presidencia/noticias/ 21052004biomas.shtm [Accessed: 01/VI/2013].

Johnson, J.B.; J.E. Gates \& N.P. Zegre. 2011. Monitoring seasonal bat activity on a coastal barrier island in Maryland, USA. Environmental Monitoring and Assessment 173 (1): 685699. doi: 10.1007/s10661-010-1415-6.

Jones, G.; D.S. Jacobs; T.H. Kunz; M.R. Willig \& P.A. Racey. 2009. Carpe noctem: the importance of bats as bioindicators. Endangered Species Research 8 (1-2): 93-115. doi: 10.3354/ esr00182.

Kofoky, A.; D. Andriafidison; F. Ratrimomanarivo; H. J. Razafimanahaka; D. Rakotondravony; P.A. Racey \& R.K.B. JENKINs. 2007. Habitat use, roost selection and conservation of bats in Tsingy de Bemaraha National Park, Madagascar. Biodiversity and Conservation 16 (4): 1039-1053. doi: 10.1007/s10531-006-9059-0.

Kuenzi, A.J. \& M.L. Morrison. 2003. Temporal Patterns of Bat Activity in Southern Arizona. Journal of Wildlife Management 67 (1): 52-64.

KunZ, T.H. 1973. Resource utilization: temporal and spatial components of bat activity in central Iowa. Journal of Mammalogy 54 (1): 14-32.

LACKI, M.J. 1984. Temperature and humidity-induced shifts in the flight activity of little brown bats. The Ohio Journal of Science 84 (5): 264-266.

LEWIS, T.S. 1970. Patterns of distribution of insects near a windbreak of tall trees. Annals of Applied Biology 65 (2): 213-220. doi: 10.1111/j.1744-7348.1970.tb04581.x.

Limpens, H.J.G.A. \& K. KaPTeYN. 1991. Bats, their behaviour and linear landscape elements. Myotis 29: 63-71.

Lumsden, L.F. \& A.F. Bennetr. 2005. Scattered trees in rural landscapes: foraging habitat for insectivorous bats in southeastern Australia. Biological Conservation 122 (2): 205222. doi:10.1016/j.biocon.2004.07.006. 
Lunde, R.E. \& A.S. Harestad. 1986. Activity of Little Brown Bats in Coastal Forest. Northwest Science 60 (4): 206-209.

Morris, A.D.; D.A. Miller \& M.C. Kalcounis-Rueppell. 2010. Use of forest edges by bats in a managed pine forest landscape. Journal of Wildlife Management 74 (1): 26-34. doi: 10.2193/2008-471.

Neuweiler, G. 2000. The biology of bats. Oxford, Oxford University Press, VI+310p.

O'DonnelL, C.F.J. 2000. Conservation status and causes of decline of a threatened New Zealand Long-tailed bat Chalinolobus tuberculatus (Chiroptera: Vespertilionidae). Mammal Review 30 (2): 89-106. doi: 10.1046/j.13652907.2000.00059.x.

O'Farrell, M.J. \& Bradley W.G. 1970. Activity Patterns of Bats over a Desert Spring. Journal of Mammalogy 51 (1): 18-26.

O'Farrell, M.J.; W.G. BradLey \& G.W. Jones. 1967. Fall and winter bat activity at a desert spring in Southern Nevada. The Southwestern Naturalist 12 (2): 163-171.

Paglia, A.P.; G.A.B. Fonseca \& J.M.C. Silva. 2008. A Fauna Brasileira Ameaçada de Extinção: Síntese Taxonômica e Geográfica, p. 63-70. In: A.B.M. Machado; G.M. Drummond \& A.P. Paglia (Eds). Livro Vermelho da Fauna Brasileira Ameaçada de Extinção. Belo Horizonte, Fundação Biodiversitas, vol. 2, 908p.

Parsons, S. \& J.M. Szewczak. 2009. Detecting, Recording, and Analyzing the Vocalizations of Bats, p. 91-111. In: T.H. Kunz $\&$ S. PARSONS (Eds). Ecological and behavioral methods for the study of bats. Baltimore, The Johns Hopkins University Press, XVII+901p.

Peel, M.C.; B.L. Finlayson \& T.A. McMahon. 2007. Updated world map of the Köppen-Geiger climate classification. Hydrology and Earth System Sciences 11 (5): 1633-1644. doi: 10.5194/ hess-11-1633-2007.

PetTit, T.W. \& K.T. Wilkins. 2012. Canopy and edge activity of bats in a quaking aspen (Populus tremuloides) forest. Canadian Journal of Zoology 90 (7): 798-807. doi:10.1139/Z2012-049.

Pierson, E.D. 1998. Tall Trees, Deep Holes, and Scarred Landscapes - Conservation Biology of North American Bats, p. 309-325. In: T.H. Kunz \& P.A. RACEY (Eds). Bat biology and conservation. Washington, D.C., Smithsonian Institution Press, XIV+365p.

Pillar, V.P.; S.C. Müller; Z.M.S. Castilhos \& A.V.A. Jacques. 2009. Campos Sulinos - Conservação e Uso Sustentável da Biodiversidade. Brasília, Ministério do Meio Ambiente, 403p.

Racey, P.A. \& S.M. Swift. 1985. Feeding ecology of Pipistrellus pipistrellus (Chiropteran: Vespertilionidae) during pregnancy and lactation - I. Foraging behaviour. Journal of Animal Ecology 54 (1): 205-215.

Rамво, B. 2000. A fisionomia do Rio Grande do Sul: ensaio de monografia natural. São Leopoldo, Editora Unisinos, $3^{\text {rd }}$ ed., XXVII+473p.

Ransome, R.D. 1990. The Natural History of Hibernating Bats. London, Christopher Helm, XXI+235p.
Rio Grande do Sul. 2002. Decreto Estadual No 42.099, de 31 de dezembro de 2002. Declara as espécies da flora nativa ameaçadas de extinção no estado do Rio Grande do Sul e dá outras providências. Porto Alegre, Diário Oficial do estado do Rio Grande do Sul de 01/01/2003.

Russ, J.M.; M. Briffa \& W.I. Montgomery. 2003. Seasonal patterns in activity and habitat use by bats (Pipistrellus spp. and Nyctalus leisleri) in Northern Ireland, determined using a driven transect. Journal of Zoology 259 (3): 289-299. doi: $10.1017 /$ S0952836902003254.

Russo, D. \& G. JONES. 2003. Use of foraging habitats by bats in a Mediterranean area determined by acoustic surveys: conseration implications. Ecography 26 (2): 197-209. doi: 10.1034/j.1600-0587.2003.03422.x.

Serra-Cobo, J.; M. Lopez-Roig; T. Marques-Bonet \& E. Lahuerta. 2000. Rivers as possible landmarks in the orientation flight of Miniopterus schreibersii. Acta Theriologica 45 (3): 347-352.

Siemers, B.M.; P. Stilz \& H. Schnitzler. 2001. The acoustic advantage of hunting at low heights above water: behavioural experiments on the European 'trawling' bats Myotis capaccinii, M. dasycneme and $M$. daubentonii. The Journal of Experimental Biology 204 (22): 3843-3854.

Simmons, N.B. 2005. Order Chiroptera, p. 312-529. In: D.E. WILSON \& D.M. REEDER (Eds). Mammal species of the world: a taxonomic and geographic reference. Baltimore, The Johns Hopkins University Press, vol. 1, XXXV+743p.

TAYLOR, L.R. 1963. Analysis of the Effect of Temperature on Insects in Flight. Journal of Animal Ecology 32 (1): 99-117.

Tuttle, M.D. 1979. Status, Causes of Decline, and Management of Endangered Gray Bats. The Journal of Wildlife Management 43 (1): 1-17.

Vaughan, N.; G. Jones \& S. Harris. 1997. Habitat use by bats (Chiroptera) assessed by means of a broad-band acoustic method. Journal of Applied Ecology 34 (3): 716-730.

Verboom, B. \& K. Spoelstra. 1999. Effects of food abundance and wind on the use of tree lines by an insectivorous bat, Pipistrellus pipistrellus. Canadian Journal of Zoology 77 (9): 1393-1401. doi: 10.1139/z99-116.

WaLSH, A.L. \& S. HaRRIS. 1996. Foraging habitat preferences of vespertilionid bats in Britain. Journal of Applied Ecology 33 (3): 508-518.

Wickramasinghe, L.P.; S. Harris; G. Jones \& N. Vaughan. 2003. Bat activity and species richness on organic and conventional farms: impact of agricultural intensification. Journal of Applied Ecology 40 (6): 984-993. doi: 10.1111/j.13652664.2003.00856.x.

WoldA, H. 1988. Insect Seasonality: Why? Annual Review of Ecology and Systematics 19: 1-18. doi: 10.1146/ annurev.es.19.110188.000245.

Submitted: 05.IX.2013; Accepted: 16.III.2014. Editorial responsibility: Fernando de C. Passos 